\title{
INDICATORS OF PROTEIN METABOLISM IN CALVES WITH BRONCHOPNEUMONIA UNDER INDIVIDUAL THERAPY
}

\author{
M. V. DROBOT, Graduate Student \\ Department of Therapy and Clinical Diagnosis \\ https://orcid.org/0000-0002-6852-2003 \\ National University of Life and Environmental Sciences of Ukraine \\ E-mail:drobot_mv@meta.ua
}

\begin{abstract}
Respiratory diseases of animals are a significant problem in veterinary medicine. They cause a lot of economic damage to farms, consisting of decreasing productivity and breeding qualities of animals and their deaths. The significant spread of respiratory diseases in animals is caused by decreasing natural resistance due to violation of the housing technology, as well as a high concentration of opportunistic and pathogenic microflora in the indoor air.

The results of individual therapy in calves with nonspecific catarrhal bronchopneumonia with the use of the drug Calfmin, which is based on compounds of biogenic micro- and macroelements, and plant immunomodulators, are presented. The clinical parameters of calves, namely, habitus, condition of hair, skin, visible mucous membranes, superficial lymph nodes, body temperature, number of respiratory movements, and heart contractions were studied during bronchopneumonia and their changes under individual treatment of animals.

The indicators of protein metabolism in the blood serum of clinically healthy and calves with nonspecific bronchopneumonia were also studied. The content of total protein, albumin, $\alpha$-, $b$ - and $\gamma$-globulins was examined in the blood serum of calves by nephelometric method using phosphate buffers. The dynamics of the comparative analysis of total protein content and its fractions in the blood serum between calves of separate experimental groups is shown. The results of studies indicate a decrease in the body's natural resistance and suppression of immunity in sick calves and the rapid recovery under the conditions of the application of nanoaquachelate macronutrients in the form of the drug Calfmin in combination with Echinacea.
\end{abstract}

Keywords: calves, nonspecific bronchopneumonia, clinical parameters, total protein, albumins, globulins, natural resistance

\footnotetext{
* Scientific supervisor - Doctor of Biological Sciences, Professor M. I. Tsvilikhovskyi
} 


\section{Introduction}

Dairy farming in Ukraine has always been, and is now, a traditional and dominant branch of animal husbandry, which is the main part of providing the population with food. However, prolonged general economic instability and underfunding of this livestock industry provokes a violation of animal husbandry technology, which is often manifested by unsatisfactory housing conditions, insufficient provision of animals complete feed rations, etc. (Chumachenko et al., 2000; Ruda, 2000). As a result, the natural resistance is significantly reduced in the cattle, which is manifested by the low level of immunobiological reactivity in calves (Ruda, 2000; Chumachenko et al., 2000; Griffin et al., 2010). Such calves are usually prone to diseases of various etiologies. The diseases of the digestive tract (dyspepsia) and respiratory (bronchopneumonia) system are very often registered.

Respiratory diseases of animals are a significant problem in veterinary medicine. They cause a lot of economic damage to farms, consisting of decreasing productivity and breeding qualities of animals and their deaths (Demidchik, 2005; Antonenko, 2007; Bliznetsova et al., 2008).

Diseases of the respiratory system are widespread among animals of all species and age groups but are more commonly diagnosed in young, exhausted, and old animals (Ruda, 2000; Kondrakhin et al., 2012; Wolfger et al., 2015). In modern economic conditions, respiratory diseases of young animals are widespread in Ukraine (Tatarchyk, 2007) and abroad (Tuleva, 2007; Slupsky et al., 2009; Trofimov et al., 2009; Basoglu et al., 2016), and could be both in large high-tech farms of industrial type or small farms (Chumachenko et al., 2000; Slupsky, 2009).
The significant spread of respiratory diseases of animals is caused by decreasing the natural resistance due to violation of the housing technology, as well as a high concentration of opportunistic and pathogenic microflora in the indoor air (Tuleva, 2009; Basoglu et al., 2016; Braun et al., 2018;).

Approximately $20-30 \%$ of calves suffer from bronchopneumonia in Ukraine every year. The disease mainly occurs in winter and spring. Risk groups are calves at the age from 2 weeks to 2-3 months (Tatarchyk, 2007; Griffin et al., 2010; Kondrakhin et al., 2011).

In the etiology of nonspecific bronchopneumonia in calves in combination with reduced resistance, immunological reactivity of the newborn animals, and the influence of adverse environmental factors, the bacterial microflora of the upper respiratory tract plays an important role, which under certain conditions becomes pathogenic (Nicholas et al., 2008; Trofimov et al., 2009; Basoglu et al., 2016).

In recent years, the incidence of calves with bronchopneumonia has increased due to a decrease in their body's natural resistance, suppression of immunity, and lack of scientifically sound means and methods of prevention and treatment of animals.

During bronchopneumonia in calves, pathological processes develop not only in the respiratory system but also in the whole body, because all types of metabolism are impaired. This, in turn, leads to the suppression of the functions of all vital organs and systems in animals. Therefore, to achieve the desired result, it is important to take a comprehensive approach when choosing drugs for the treatment of patients with bronchopneumonia in calves (Tatarchyk, 2007; Wolfger et al., 2015; Zitzmann et al., 2019;). 
The economic losses from bronchopneumonia consist of a significant percentage of calf deaths, a decrease in the average daily weight gain (sick calves have a lack of growth and development), the cost of veterinary care, and additional treatment for sick animals (Dariusz et al., 2003; Jodi et al., 2020).

The most effective is a comprehensive treatment of calves with bronchopneumonia, which should be aimed at eliminating violations of the keeping and feeding technology, increase the natural resistance, and includes the simultaneous use of various therapies: antimicrobial, pathogenetic, symptomatic, application of stimulants and vitamins.

That is why, nowadays, the development and introduction into the practice of veterinary medicine of new highly effective and cost-effective schemes for the prevention of nonspecific bronchopneumonia and treatment of calves with this pathology are especially relevant.

The purpose of this work is to study the metabolism of proteins and their fractions in the blood serum of calves with nonspecific bronchopneumonia under individual therapy using nanoaquachelates of macronutrients in the form of a drug Calfmin in combination with Echinacea.

\section{Materials and methods of research}

The research was conducted in the farm "Podilskyi Gospodar 2004", a village of Velyka Medvedivka, Shepetivka district, Khmelnytskyi region.

Four groups of black-spotted calves aged 2 months were formed for the study: one control (clinically healthy calves) and three experimental (calves with nonspecific acute catarrhal bronchopneumonia), seven animals in each group.
During the selection of calves into groups, the results of clinical trials obtained using the methods of examination, thermometry, percussion, and auscultation were taken into account, and the infectious nature of bronchopneumonia was excluded.

Sick calves of the $1^{\text {st }}$ experimental group were treated due to the treatment regimen used in the farm (basic treatment): calves were injected intramuscularly with a combined antibiotic Combikel at a dose of $1 \mathrm{ml}$ per $10 \mathrm{~kg}$ of body weight, anti-inflammatory drug Dexakelum at a dose of $1 \mathrm{ml}$ per $100 \mathrm{~kg}$ of body weight body, and hepatoprotector HEPAVI-kel at a dose of $1 \mathrm{ml}$ per 10 $\mathrm{kg}$ of body weight.

Calves of the $2^{\text {nd }}$ experimental group received basic treatment according to the scheme used in the farm and, in addition, they were given the immunomodulator N (D-8) with milk.

Calves of the $3^{\text {rd }}$ experimental group were treated using only nanoaquachelates of micronutrients in the form of the drug Calfmin and plant immunomodulator Echinacea. The drugs were used dissolved in 1 liter of milk at a dose per animal of $3.5 \mathrm{ml}$ of Calfmin and $1.25 \mathrm{ml}$ of Echinacea, the frequency of application - twice a day.

Monitoring of the clinical condition in calves and the course of the disease was carried out daily throughout the treatment period, and biochemical examinations were performed on the $1^{\text {st }}$ day of the disease, and the $3^{\text {rd }}$ and $7^{\text {th }}$ day of treatment.

Blood samples were taken from the jugular vein in the morning before feeding. The content of total protein and its fractions was determined. The results of the research were processed statistically using the program named Statistica. 


\section{Results of the research and their discussion}

It is established that in the farm "Podilskyi Gospodar 2004" of Khmelnytskyi region, the winter-spring outbreak of bronchopneumonia in calves begins in February with the maximum number of sick animals and their further deaths in March and April. The results of our research indicate that the farm has susceptible to disease calves at the age of 1-3 months, and our long-term monitoring of the incidence of calves with nonspecific acute catarrhal bronchopneumonia showed that on average during 2006-2018 in this farm, nearly $23.1-24.7 \%$ of calves become sick and nearly $7.2-9.4 \%$ of them died from this pathology at age of 1-2 months and $3.4-6.3 \%$ - at age of 23 months.

During the research, we found that the rate of survived 1-2 months old calves with bronchopneumonia is up to $90.6 \%$, which indicates the low efficiency of treatment schemes. The number of 2-3 months old calves suffering from bronchopneumonia after treatment according to the scheme of the farm was slightly higher and amounted to $93.2 \%$.

The study of etiopathogenetic relationships under nonspecific acute catarrhal bronchopneumonia in calves on the farm made it possible to identify several groups of etiological factors that affect the body of calves of different ages in different combinations.

The first group includes anthropogenic factors, disorders of biogeocenosis, and adverse factors of fetal development. They lead to the birth of malnourished calves with weakened resistance, which is confirmed by such criteria as the body temperature immediately after birth. Thus, the temperature of some calves was not $39.1-39.3{ }^{\circ} \mathrm{C}$ but reduced by $1-1.5^{\circ} \mathrm{C}$.
These calves showed bradycardia, myopathy, and malnutrition. The sucking reflex in many newborn calves was weak with a delay. Most of these calves had dyspepsia and often developed bronchopneumonia in some time after recovering from dyspepsia. This indicates that the diseases of young animals in the neonatal period are associated with their anatomical and physiological characteristics.

According to our data, the prevalence of diseases in newborn calves under the scheme "dyspepsia - bronchopneumonia" is due to the violation of the conditions for keeping and feeding cows of breeding stock under their different physiological conditions. It is necessary to highlight the insufficient feed base, violation of the diet structure, especially in the dry season, insufficient feed quality and deficiency of macro-, micronutrients, and vitamins.Nonspecific catarrhal bronchopneumonia occurs in calves on the farm also due to a violation of the diet structure and housing conditions of animals in the postnatal period. Among this group of etiological factors, we distinguish the following: congestion, accumulation of harmful gases, colds (cold, high humidity). Analysis of the diet showed that the feed base for 1.5-2 months old calves does not provide the physiological need for protein, vitamins, especially A, $\mathrm{C}$, as well as macro- and microelements, especially iodine and calcium.

In a clinical study, sick calves showed general weakness, loss of appetite, redness of the conjunctiva and mucous membranes of the nasal cavity, the appearance of catarrhal discharge, and dry painful cough. Respiration in animals was accelerated, difficult and shallow, abdominal type (Table 1). Sick calves laid down most of the time, when they were forced to get up, there was an unconfident gait, muscle tremor. The hair was disheveled, wet. 


\section{Clinical parameters in calves with bronchopneumonia under individual therapy $(\mathbf{M} \pm \mathbf{m}, \mathbf{n}=7)$}

\begin{tabular}{|c|c|c|c|c|}
\hline \multirow[b]{2}{*}{ Period } & \multirow[b]{2}{*}{$\begin{array}{c}\text { Clinically healthy } \\
\text { calves (control } \\
\text { group) }\end{array}$} & \multicolumn{3}{|c|}{ Sick calves } \\
\hline & & $\begin{array}{l}1^{\text {st }} \text { experimental } \\
\text { group (basic } \\
\text { treatment) }\end{array}$ & $\begin{array}{c}2^{\text {nd }} \text { experimental } \\
\text { group (basic } \\
\text { treatment }+ \text { D-8) }\end{array}$ & $\begin{array}{l}3^{\text {rd }} \text { experimental } \\
\text { group (Calfmin }+ \\
\text { Echinacea) }\end{array}$ \\
\hline \multicolumn{5}{|c|}{ Body temperature, ${ }^{\circ} \mathrm{C}$} \\
\hline $1^{\text {st }}$ day & $38.80 \pm 0.16$ & $40.84 \pm 0.21^{* * *}$ & $40.95 \pm 0.21^{* * *}$ & $40.87 \pm 0.23^{* * *}$ \\
\hline $3^{\text {rd day }}$ & $38.99 \pm 0.06$ & $39.50 \pm 0.17^{*}$ & $39.30 \pm 0.18$ & $39.11 \pm 0.09$ \\
\hline $7^{\text {th }}$ day & $38.90 \pm 0.07$ & $39.01 \pm 0.12$ & $38.94 \pm 0.09$ & $38.87 \pm 0.10$ \\
\hline \multicolumn{5}{|c|}{ Pulse rate, beats/min } \\
\hline $1^{\text {st }}$ day & $78.14 \pm 0.96$ & $97.29 \pm 1.14^{* * *}$ & $96.14 \pm 1.41^{* * *}$ & $97.57 \pm 1.05^{* * *}$ \\
\hline $3^{\text {rd day }}$ & $78.86 \pm 1.32$ & $88.86 \pm 1.13^{* * *}$ & $86.86 \pm 1.43^{* * *}$ & $85.29 \pm 1.53^{* *}$ \\
\hline $7^{\text {th }}$ day & $76.86 \pm 1.48$ & $78.14 \pm 2.32$ & $77.71 \pm 1.88$ & $76.14 \pm 1.43$ \\
\hline \multicolumn{5}{|c|}{ The number of respiratory movements per $1 \mathrm{~min}$} \\
\hline $1^{\text {st }}$ day & $29.43 \pm 0.60$ & $46.57 \pm 0.94^{* * *}$ & $46.43 \pm 1.34^{* * *}$ & $46.71 \pm 1.41^{* * *}$ \\
\hline $3^{\text {rd }}$ day & $28.43 \pm 0.75$ & $37.29 \pm 1.51^{* * *}$ & $35.29 \pm 1.48^{* * *}$ & $34.43 \pm 1.52^{* *}$ \\
\hline $7^{\text {th }}$ day & $28.14 \pm 0.47$ & $29.57 \pm 1.19$ & $29.29 \pm 0.63$ & $28.57 \pm 0.57$ \\
\hline
\end{tabular}

Note: hereinafter $* \mathrm{P}<0.05, * * \mathrm{P}<0.01, * * * \mathrm{P}<0.001$ compared to clinically healthy calves.

On the $1^{\text {st }}$ day of researches, the body temperature in calves of all experimental groups was $40.84-40.95^{\circ} \mathrm{C}$, which is significantly higher by 1.04 $1.15{ }^{\circ} \mathrm{C}(\mathrm{P}<0.001)$ compared with clinically healthy animals. The number of heart contractions in calves with bronchopneumonia was in the range of 96-97 beats per minute, which is also significantly higher than in clinically healthy animals in 1.25 times $(\mathrm{P}<0.001)$. The conjunctiva and nasal mirror in sick calves had a cyanotic shade, indicating a violation of hemostasis in the small circulation. The number of respiratory movements in calves of the experimental groups was in the range of 46.4-46.7, which is 1.58 times significantly higher $(\mathrm{P}<0.001)$ than in clinically healthy calves (Table 1). The mixed-type shortness of breath, a sharp, dry, intermittent, painful cough, a discharge of catarrhal exudate from nasal passages were also observed. Wet rales were detected during auscultation of the heart, which indicates a violation of the elastic properties of the interalveolar septa due to the accumulation of exudate in them. Also, muffled heart sounds and weakening of the pulse wave were noted during auscultation of the heart. Chest percussion revealed a focus of dullness in the apical and cardiac parts of the lungs.

Our data on protein metabolism in calves with bronchopneumonia indicate the presence of hypoproteinemia under this pathology.

Thus, the total protein content in the blood serum of calves with bronchopneumonia in the experimental groups is significantly lower by $12-13 \%$ $(\mathrm{P}<0.05)$ compared with clinically healthy calves (Table 2). According to our data, this is mainly due to proteins of the albumin fraction. 


\section{Indicators of protein metabolism in the blood serum of calves with catarrhal bronchopneumonia under individual therapy $(\mathbf{M} \pm \mathbf{m}, \mathbf{n}=7)$}

\begin{tabular}{|c|c|c|c|c|}
\hline \multirow[b]{2}{*}{ Period } & \multirow[b]{2}{*}{$\begin{array}{l}\text { Clinically healthy } \\
\text { calves (control } \\
\text { group) }\end{array}$} & \multicolumn{3}{|c|}{ Sick calves } \\
\hline & & $\begin{array}{l}1^{\text {st }} \text { experimental } \\
\text { (basic treatment) }\end{array}$ & $\begin{array}{c}2^{\text {nd }} \text { experimental } \\
\text { group (basic treat- } \\
\text { ment }+ \text { D- } 8 \text { ) }\end{array}$ & $\begin{array}{c}3^{\text {rd }} \text { experimental } \\
\text { group (Calfmin }+ \\
\text { Echinacea) }\end{array}$ \\
\hline \multicolumn{5}{|c|}{ Total protein, g/L: } \\
\hline $1^{\text {st }}$ day & $65.43 \pm 2.27$ & $58.37 \pm 2.36^{*}$ & $56.93 \pm 2.53 *$ & $57.93 \pm 2.19 *$ \\
\hline $3^{\text {rd day }}$ & $62.35 \pm 2.39$ & $59.56 \pm 2.89$ & $58.48 \pm 2.80$ & $60.68 \pm 2.99$ \\
\hline $7^{\text {th }}$ day & $62.23 \pm 4.33$ & $60.13 \pm 4.45$ & $59.05 \pm 3.64$ & $63.38 \pm 4.60$ \\
\hline \multicolumn{5}{|c|}{ Albumins, $\mathrm{g} / \mathrm{L}$ : } \\
\hline $1^{\text {st }}$ day & $27.57 \pm 2.12$ & $21.60 \pm 1.62 *$ & $20.30 \pm 1.67 *$ & $19.79 \pm 1.68 * *$ \\
\hline $3^{\text {rd day }}$ & $25.59 \pm 1.45$ & $23.32 \pm 1.15$ & $22.13 \pm 1.66$ & $22.12 \pm 1.43$ \\
\hline $7^{\text {th }}$ day & $26.55 \pm 2.44$ & $24.54 \pm 2.08$ & $23.36 \pm 3.05$ & $26.07 \pm 2.35$ \\
\hline \multicolumn{5}{|c|}{ Globulins, g/L: } \\
\hline $1^{\text {st }}$ day & $37.86 \pm 2.34$ & $36.77 \pm 3.15$ & $36.63 \pm 2.76$ & $38.14 \pm 2.22$ \\
\hline $3^{\text {rd }}$ day & $36.76 \pm 3.55$ & $36.24 \pm 4.05$ & $36.35 \pm 3.33$ & $38.56 \pm 3.98$ \\
\hline $7^{\text {th }}$ day & $35.68 \pm 2.67$ & $35.59 \pm 2.78$ & $35.69 \pm 2.45$ & $37.31 \pm 3.74$ \\
\hline \multicolumn{5}{|c|}{$\alpha$-Globulins, $\mathrm{g} / \mathrm{L}$ : } \\
\hline $1^{\text {st }}$ day & $7.87 \pm 1.12$ & $8.70 \pm 1.11$ & $9.47 \pm 2.23$ & $8.83 \pm 2.43$ \\
\hline $3^{\text {rd day }}$ & $8.15 \pm 1.78$ & $8.17 \pm 2.45$ & $8.35 \pm 1.76$ & $8.49 \pm 1.55$ \\
\hline $7^{\text {th }}$ day & $8.05 \pm 1.56$ & $7.63 \pm 1.54$ & $7.85 \pm 1.76$ & $8.04 \pm 1.83$ \\
\hline \multicolumn{5}{|c|}{$\beta$-Globulins, g/L: } \\
\hline $1^{\text {st }}$ day & $7.41 \pm 1.34$ & $11.59 \pm 1.45^{*}$ & $11.11 \pm 1.95^{*}$ & $10.89 \pm 2.55^{*}$ \\
\hline $3^{\text {rd day }}$ & $8.07 \pm 1.67$ & $10.44 \pm 2.04$ & $9.23 \pm 1.82$ & $9.91 \pm 1.44$ \\
\hline $7^{\text {th }}$ day & $8.82 \pm 1.87$ & $8.95 \pm 2.65$ & $8.27 \pm 1.55$ & $8.24 \pm 2.56$ \\
\hline \multicolumn{5}{|c|}{$\gamma$-Globulins, g/L: } \\
\hline $1^{\text {st }}$ day & $20.61 \pm 2.91$ & $12.33 \pm 2.22$ & $11.43 \pm 1.11$ & $12.25 \pm 2.16$ \\
\hline $3^{\text {rd day }}$ & $19.48 \pm 1.44$ & $13.84 \pm 3.34$ & $12.08 \pm 2.05$ & $13.08 \pm 3.33$ \\
\hline $7^{\text {th }}$ day & $19.21 \pm 1.86$ & $14.62 \pm 2.64$ & $12.74 \pm 1.77$ & $15.30 \pm 1.17$ \\
\hline
\end{tabular}

Note: similar to Table 1.

The results of studies have shown that at the beginning of the treatment (1st day) the albumin content in the blood serum was $22-28 \%$, which is significantly lower $(\mathrm{P}<0.05)$ compared to clinically healthy animals.

The indicators of the globulin content in the blood serum of calves of all experimental groups at the beginning of the treatment did not differ significantly from those in clinically healthy animals. However, the albumin/globulin ratio was in the range of $0.51-0.59$ in calves of the experimental groups, while in clinically healthy animals $-0.73-0.84$.

It should be noted that the content of individual globulin fractions in the blood serum of calves with broncho- 
pneumonia differs from their content in the blood serum of clinically healthy calves. Thus, in the blood serum of calves with bronchopneumonia at the beginning of the treatment, there was a pronounced tendency to increase the content of $\alpha$ - and $\beta$-globulins and a significant decrease in the content of $\gamma$-globulins by $40-44 \%(\mathrm{P}<0.05)$ compared with clinically healthy calves.

Our treatment of calves helped to improve the metabolism of proteins in their organism.

Thus, on the $3^{\text {rd }}$ day of our research, the albumin content in the blood serum of sick calves of the experimental groups was $22-23.3 \mathrm{~g} / \mathrm{L}$, but this figure did not reach the values of clinically healthy calves $(25.59 \pm 1.45)$. That is, during this period of the treatment in calves with bronchopneumonia, there was already a pronounced tendency to increase the globulin content in their blood and the gradual approximation of this indicator to the values of clinically healthy calves (Table 2).

The total content of globulins in the blood serum of calves with bronchopneumonia on the $3^{\text {rd }}$ day of the treatment, as at the beginning, was at the level of clinically healthy calves. However, the albumin to globulin ratio in these animals on the $3^{\text {rd }}$ day of the research was in the range of $0.57-0.61$, while in clinically healthy calves -0.70 . That is, on the $3^{\text {rd }}$ day of the treatment, well-pronounced dysproteinemia was still observed in the body of sick calves.

Analyzing the content of individual globulin fractions in the blood of calves of the experimental groups, it should be noted that on the $3^{\text {rd }}$ day of the treatment of calves with bronchopneumonia compared with the $1^{\text {st }}$ day, the content of $\alpha$ - and $\beta$-globulins tended to decrease, while $\gamma$-globulins - to increase. In rela- tion to clinically healthy calves, the content of $\alpha$-globulins in the blood serum of calves with bronchopneumonia of all experimental groups during this period was at the same level, ß-globulins - had a slight tendency to increase, and $\gamma$-globulins - significantly decreased in calves of the $1^{\text {st }}$ experimental group by $28 \%(\mathrm{P}<0.05)$, the $2^{\text {nd }}-$ by $36 \%(\mathrm{P}<$ $0.05)$, and the $3^{\text {rd }}-$ by $33 \%(\mathrm{P}<0.05)$.

On the $7^{\text {th }}$ day of the therapy, the content of total protein in the blood serum of calves of the experimental groups had a pronounced tendency to increase compared to the $1^{\text {st }}$ day in animals of all groups. At the same time, the content of total protein in the blood serum of calves of the $3^{\text {rd }}$ experimental group, for the treatment of which was used the drug Calfmin in combination with Echinacea, on the $7^{\text {th }}$ day of the experiment did not differ from that in clinically healthy calves. During this period, the albumin content in the blood serum of calves of the experimental groups was within the range of clinically healthy calves, and compared with the $1^{\text {st }}$ day it increased significantly: in calves of the $1^{\text {st }}$ group - by $14 \%(\mathrm{P}<0.05)$, the $2^{\text {nd }}$ - by $15 \%(\mathrm{P}<0.05)$, and the $3^{\text {rd }}-$ by $32 \%(\mathrm{P}<0.01)$. As a result, the albumin to globulins ratio significantly increased in calves of the $1^{\text {st }}$ group to 0.69 , the $2^{\text {nd }}-0.65$, the $3^{\text {rd }}-0.70$. In the blood serum of clinically healthy calves, the albumin/globulin ratio at this time was 0.74 . The content of individual globulin fractions in the blood serum of calves of the experimental groups on the $7^{\text {th }}$ day of the experiment was characterized by the normalization of $\alpha$ - and $\beta$-globulins. At the same time, it should be noted that the blood serum protein content of the $\gamma$-globulin fraction in calves of all experimental groups decreased compared with clinically healthy calves. 


\section{Conclusions and future perspectives}

It is known that the state of hypoxia under bronchopneumonia causes changes not only in the lungs but also in other organs. Thus, a significant decrease in the total protein content in the blood serum of calves with nonspecific catarrhal bronchopneumonia is apparently due to pathological changes in the liver and other organs due to hypoxia. According to Usha (2018), in calves with bronchopneumonia due to impaired gas exchange and the development of hypoxia, there are deep structural disorders of the liver, changes in the structure of hepatocytes, they undergo degeneration, the necrosis occurs. These changes start from the center of the hepatocyte and spread to the periphery. In addition, the liver cells that are furthest from the vessels that supply them do not receive enough oxygen and other nutrients. This causes their degeneration and necrosis. Changes in the structure of separate liver cells lead to changes in the whole organ and disruption of its physiological functions. Therefore, the protein-forming function of the liver is disrupted, the albumin content decreases by 1.5 times $(\mathrm{P}<0.05)$ in the blood serum against the background of an increase in the globulin content, which leads to a decrease in albumin/globulin ratio in 1.5 times $(\mathrm{P}<0.001)$, that is, to the manifestation of dysproteinemia. According to the research of Usha and other authors (Usha et al., 2018), in the blood serum of calves with catarrhal bronchopneumonia, there is a tendency to decrease the content of $\alpha$ - and $\beta$-globulins, while the content of $\gamma$-globulins on the contrary - tends to increase. According to our data, at the beginning of the disease in the blood serum of calves with bron- chopneumonia, the content of $\alpha$-globulin fraction significantly increases, the protein content of $\beta$-globulin fraction is less pronounced, and the content of $\gamma$-globulin fraction decreases, which is consistent with other studies.

The total duration of the treatment of calves of the $3^{\text {rd }}$ experimental group, which was treated with the drug Calfmin in combination with Echinacea, averaged 7-8 days. The treatment period of calves of the $1^{\text {st }}$ experimental group lasted more than 12 days, which implies a high probability of transition of the disease to a chronic form. It should be noted that during the treatment of calves of the $1^{\text {st }}$ experimental group, one animal died.

Our results indicate a significantly higher therapeutic efficacy of the treatment of calves with catarrhal bronchopneumonia using nanoaquachelates of microlements in the form of Calfmin in combination with Echinacea, compared with the treatment of calves including the combined antibiotic Combikel, anti-inflammatory drug Dexakelum, and hepatorotector HEPAVI-kel.

The research results provide for the continuation of scientific experiments to study the effect of nanoaquachelates of microelements in combination with Echinacea on other indicators of the blood of calves with bronchopneumonia.

\section{References}

Antonenko, P. (2007). Roslinnyi preparat proty bronchopnevmoniyi u teliat [Herbal preparation against bronchopneumonia in calves]. Tvarinnytstvo Ukrayiny, 10, 32-34. (in Ukrainian)

Basoglu, A., Baspinar, N., \& Tenori, L. (2016). Plasma metabolomics in calves with acute bronchopneumonia. Metabolomics, 12, 1-10. doi: org/10.1007/s11306-0161074-x. 
Bliznetsova, H. N., Chernitskiy, A. E., \& Kovalev, A. A. (2008). Biokhimicheskie parametry kondensata bydykhaemogo vozdukha teliat [Biochemical parameters of the exhaled air condensate of calves]. Veterinariia, 3, 44-47. (in Russian)

Braun, U., Gerspach, C., \& Brammertz, C. (2018). The frequency of abnormal ultrasonographic findings in the lungs of 129 calves with bronchopneumonia. Schweiz Arch Tierheilkd, 160(12), 737-741.

Chumachenko, V. Y., Ruda, N. I., \& Varbanets, L. D. (2000). Kompleksna terapiia teliat, khvorikh na kataralnu bronchopnevmoniiu, z vukorystanniam immunomoduliatora BAY-1 [Complex therapy of calves with catarrhal bronchopneumonia using the immunomodulator BAI-1]. Naukovyi visnyk Natsionalnogho aghrarnogho universitetu, 28, 251-254. (in Ukrainian)

Bednarek, D., Zdzisińska, B., Kondracki, M., \& Kandefer-Szerszeń, M. (2003). Effect of steroidal and non-steroidal anti-inflammatory drugs in combination with long-acting oxytetracycline on non-specific immunity of calves suffering from enzootic bronchopneumonia. Veterinary microbiology, 96(1), 53-67. doi: 10.1016/s0378-1135(03)00203-7.

Demidchik, L. Gh. (2005). Nespetsificheskaia bronchopnevmoniia teliat: nezaraznie bolezni [Nonspecific bronchopneumonia of calves: non-communicable diseases]. Veterinariia s/kh zhivotnykh, 2, 30-33. (in Ukrainian)

Griffin, D., Chengappa, M. M., Kuszak, J., \& McVey, D. S. (2010). Bacterial pathogens of the bovine respiratory disease complex. Veterinary Clinics: Food Animal Practice, 2(2), 381-394.

Jodi, L., \& Sacco, R. E. (2020). The Immunology of Bovine Respiratory Disease Recent Advancements. Veterinary Clinics of North America: Food Animal Practice, 36(1), 333348. doi: 10.1016/j.cvfa.2020.03.002

Kondrakhin, I. P., Levchenko, V. I., \& Vlizlo, V. V. (2011). Dispanserizatsiia - vazhneishee zveno profilaktiki vnutrennikh bolezney zhivotnykh [Clinical examination is the most important link in the prevention of internal diseases of animals]. Veterinariia, 11, 3-6. (in Ukrainian)

van Leenen, K., Van Driessche, L., De Cremer, L., Masmeijer, C., Boyen, F., Deprez, P., \& Pardon, B. (2020). Comparison of bronchoalveolar lavage fluid bacteriology and cytology in calves classified based on combined clinical scoring and lung ultrasonography. Preventive veterinary medicine, 176, 104901.

Nicholas, R., Ayling, R., \& McAuliffe, L. (2008). Respiratory disease of small ruminants. Mycoplasma diseases of ruminants. Wallingford: CABI, 169-98.

Ruda, N. (2000). Poraznyky pryrodnoi rezistentnosti u teliat zdorovykh i khvorykh na kataralnu bronchopnevmoniiu [Indicators of natural resistance in calves healthy and patients with catarrhal bronchopneumonia]. Veterynarna medytsyna Ukrayiny, 4, 38-39. (in Ukrainian)

Slupsky, C. M., Cheypesh, A., Chao, D. V., Fu, H., Rankin, K. N., Marrie, T. J., \& Lacy, P. (2009). Streptococcus pneumoniae and Staphylococcus aureus pneumonia induce distinct metabolic responses. Journal of proteome research, 8(6), 3029-3036. doi:org/10.1021/pr900103y.

Tatarchyk, O. P. (2007). Aerozolnaia terapiia bronchopnevmonii $v$ zhivotnovodstve [Aerosol therapy of bronchopneumonia in animal husbandry]. Efektivne tvarynnytstvo, 5, 37-39. (in Ukrainian)

Trofimov, A. F., Shliakhtynov, V. I., \& Muzyka, A. A. (2009). Tekhnologhiia polucheniia i vyraschivaniia novorozhdennykh teliat [Technology for obtaining and raising newborn calves]. Suchasna veterinarna medytsyna, 2, 20-25 (in Ukrainian)

Tuleva, N. P. (2007). Nespetsificheskaia immunoprofilaktika respiratornykh bolezney teliat [Nonspecific immunoprophylaxis of respiratory diseases in calves]. Veterinariia selskokhoziaystvennykh zhivotnykh, 12, 4950 (in Russian) 
Usha V.B., \& Belakov I.M. (2018). Osnovu klinicheskoy diagnostiki i veterinarnoy propedevtiki [Fundamentals of Clinical Diagnostics and Veterinary Propedeutics], 520 (in Russian)

Van Der Fels-Klerx, H. J., Saatkamp, H. W., Verhoeff, J., \& Dijkhuizen, A. A. (2002). Effects of bovine respiratory disease on the productivity of dairy heifers quantified by experts. Livestock Production Science, 75(2),157-166.

Wolfger, S. O. (2015). A Systematic Review of Bovine Respiratory Disease Diagnosis Focused on Diagnostic Confirmation, Early Detection, and Prediction of Unfavorable Outcomes in Feedlot Cattle. Veterinary Clinics of North America Food Animal, 351-365.

Zitzmann, R., Pfeffer, M., Söllner-Donat, S., \& Donat, K. (2019). Risk factors for calf mortality influence the occurrence of antibodies against the pathogens of enzootic bronchopneumonia. Tierarztliche Praxis. Ausgabe G, Grosstiere/Nutztiere, 47(3), 151-165.

\section{М. В. Дробот (2020). ПОКАЗНИКИ ОБМІНУ БІЛКІВ В ОРГАНІЗМІ ХВОРИХ} НА БРОНХОПНЕВМОНІЮ ТЕЛЯТ ЗА ІНДИВІДУАЛЬНОї ТЕРАПІї. Ukrainian Journal of Veterinary Sciences, 11(4): 61-70, https://doi.org/10.31548/ujvs2020.04.007

Анотація. Респіраторні хвороби тварин $\epsilon$ значною проблемою ветеринарної медицини. Вони завдають значних економічних збитків господарствам, що складаються зі зниження продуктивних та племінних якостей тварин і їхньої загибелі. значне поширення респіраторних хвороб тварин зумовлене зниженням природної резистентності їхнього організму внаслідок порушення технології утримання, а також високою концентрацією умовно-патогенної й патогенної мікрофлори в повітрі приміщень.

Представлені результати індивідуальної терапії хворих на неспецифічну катаральну бронхопневмонію телят за застосування їм препарату Кальфрмін, що створений на основі сполук біогенних мікро- і макроелементів та рослинних імуномодуляторів. Досліджені клінічні показники телят, а саме, габітус, стан волосяного покриву, шкіри, видимих слизових оболонок, поверхневих лімфатичних вузлів, температура тіла, кількість дихальних рухів та скорочень серия за бронхопневмонії та їхні зміни за індивідуальної терапії тварин.

Досліджені показники обміну білків у сироватці крові клінічно здорових і хворих на неспецифічну бронхопневмонію телят. Вміст загального білку, альбумінів, $\alpha$-, 6 - і ү-глобулінів досліджували в сироватці крові телят нефелометричним методом із використанням фосфатних буферів. Показано динаміку порівняльного аналізу вмісту загального білка та його фракцій у сироватці крові між телятами окремих дослідних груп. Результати досліджень вказують на зниження природної резистентності організму $і$ пригнічення імунітету у хворих телят та швидке відновлення цих показників за умов застосування тваринам наноаквахелатів мікроелементів у формі препарату Кальфмін у комплексі з ехінацеєю.

Ключові слова: телята, неспецифічна бронхопневмонія, клінічні показники, білок загальний, альбуміни, глобуліни, природна резистентність 